\title{
Volume Three \\ TABLE OF CONTENTS
}

1967 - NUMBER ONE

Autologous Agglutinators to Erythrocytes Sensitized with the Ripley Anti-Rh Antibody Digested with 14 Different Proteolytic Enzymes

Marion Waller, Richmond, Virginia

Sporotrichosis: The Significance of Variations in Morphology of Spores in the Tissues

HARRY I. LURIE, Richmond, Virginia

13

Traumatic Hyphema: A Review of Experience at the Medical College of Virginia During the Past Decade

Walter J. Geeraets, Ching-hung LiU, and DuPont GUERRY, III, Richmond, Virginia

Symposium on Pelvic Surgery:

The 1966 McGuire Lectures and Symposium

Randolph H. Hoge, Richmond, Virginia, Guest Editor

The Role of the Physician in Family Planning

Howard C. TaYlor, JR., New York, New York 27

Surgical Treatment or Irradiation of Cervical Cancer

Werner Bickenbach, Munich, Germany

35

On the Concept of Radicalism in Surgery for Cervical Cancer

Nicholas C. Louros, Athens, Greece

40

Results of 600 Wertheim Operations for Cancer of the Cervix

OTto Käser, Frankfurt, Germany

Continuing Experience in the Combination of

Radiotherapy and Surgery in the Treatment of Uterine Cancer

John A. Stallworthy, Oxford, England

Ovarian Cancer: Diagnosis and Treatment

HANS-L. KotTmeier, Stockholm, Sweden

47

Complications of X-Irradiation Therapy of Pelvic Malignancy

Michael R. Deddish, New York, New York

54

Urological Complications in Relation to the Treatment of Cervical Cancer

Tassilo Antoine, Vienna, Austria

56

Total Treatment of Endometriosis

Clayton T. Beecham, Danville, Pennsylvania

60
Exstrophy of the Bladder: Its Variations and Causation (abstract)

Victor F. Marshall, New York, New York 63

Contributors to this Issue 64

1967 - NUMBER TWO

Twentieth Annual Stoneburner Lecture Series: Clinical Pharmacology and Therapeutics

Epidemiology of Adverse Drug Reactions

Leighton E. Cluff, Gainesville, Florida

72

Pharmacology of Anti-Anginal Agents

Maurice McGregor, Montreal, Canada

77

Some Perspectives on Immunosuppressive Drugs

Robert S. Schwartz, Boston, Massachusetts

80

The Pharmacology of Newer Diuretics

Albert J. Wasserman, Richmond, Virginia

82

Iatrogenic Disorders

Robert H. Moser, San Antonio, Texas

The Treatment of Anxiety

John J. Schwab and Nancy H. McGinnis, Gainesville, Florida

The Physician as Humanist

George T. Harrell, Hershey, Pennsylvania 107

The Controversy over Generic Equivalency of Drugs

WERnER LOWENTHAL, Richmond, Virginia

113

Perspectives and Prospects in the Chemotherapy of Gastrointestinal Cancer

William Regelson, Richmond, Virginia 119

Contributors to this Issue

128

1967 - NUMBER THREE

Origins of Congenital Defects: Epidemiologic Approach

Robert W. Miller, Bethesda, Maryland

136

Diagnostic Ultrasonography

Joseph H. Holmes, Denver, Colorado

139 
Continuing Education for What?

George E. Miller, Chicago, Illinois

152

Adrenergic Stimulation and Sodium Transport

Charles O. Watlington, Richmond, Virginia 157

Contributors to this Issue

1967 - NUMBER FOUR

Symposium on Intracellular $p \mathrm{H}, \mathrm{PCO}_{2}$ and $\mathrm{PO}_{2}$

ERnst G. HuF, Richmond, Virginia, Guest Editor

Introductory Remarks

John L. Patterson, JR., Richmond, Virginia, Chairman

168

Oxygen Tension: Direct Observations on the Critical Level for the Brain

Frans F. JöbsIs, Durham, North Carolina 169

Discussion

182

Intracellular $\mathrm{CO}_{2}$ Tension: Practice and Theory

Eugene D. Robin, Pittsburgh, Pennsylvania 189

Discussion 194

Intracellular $\mathrm{pH}$ Determination by Means of $\mathrm{pH}$ Glass Microelectrodes

Norman W. Carter, Dallas, Texas

Discussion

Contributors to this Issue

Index to Volume Three 